\title{
Selection of DNA Isolation Method and PCR Protocol for the Study of Endemic Astragalus exscapus L. ssp. Transsilvanicus (Schur) Nyár
}

\author{
Katalin SZABO ${ }^{1 *}$, Cristian Radu SISEA ${ }^{1 *}$, Rodica POP ${ }^{1)}$, Monica BODEA ${ }^{1)}$, \\ Ioana Virginia BERINDEAN ${ }^{11}$, Alexandru Sabin BĂDĂRĂU ${ }^{2)}$, Doru PAMFIL ${ }^{1)}$ \\ ${ }^{1)}$ University of Agricultural Sciences and Veterinary Medicine Cluj-Napoca, Calea Manastur 3-5, \\ 400372 Cluj-Napoca, Romania.
}

${ }^{2)}$ Department of Geography, "Babeș-Bolyai” University, Cluj-Napoca, Romania.

${ }^{*}$ Corresponding author, e-mail: katalin.szabo@usamvcluj.ro; cristisisea@yahoo.com

BulletinUASVM Horticulture 72(1) / 2015

Print ISSN 1843-5254, Electronic ISSN 1843-5394

DOI:10.15835/buasvmcn-hort:11056

\begin{abstract}
Astragalus exscapus (Fabaceae) is a melliferous, perennial plant, which fits within a rarity type characterized by having small populations of relatively high habitat specificity. Astragalus exscapus L. ssp. transsilvanicus (Schur) Nyár., the endemic subspecies that we inspect, is considered vulnerable and needs special protection. In order to establish conservation strategies and to characterize polymorphism of the threatened subspecies, genetic and morphologic analysis will be implemented. Our study describes the application and development of SRAP procedures to A. exscapus ssp. transsilvanicus, including sampling, DNA extraction, PCR amplification and electrophoresis. Sequence Related Amplified Polymorphism (SRAP) molecular marker system is going to be applied to samples from eight different populations of $A$. exscapus ssp. transsilvanicus to identify the degree of polymorphism and to determine the survival potential of the subspecies. The results confirmed the suitability of the DNA extraction method to be applied and the optimal PCR protocol of the SRAP technique for large-scale studies we are performing on this vulnerable subspecies.
\end{abstract}

Keywords: Astragalus exscapus, DNA isolation, endemic species, SRAP

\section{INTRODUCTION}

Astragalus exscapus (Fabaceae) is a rare perennial plant originating from Eurasia. In Europe it is restricted to dry and semiarid regions because of its relatively high habitat specificity. Astragalus exscapus L. ssp. transsilvanicus (Schur) Nyár. is an endemic subspecies (Podlech, 1988) with only 24 populations localized in the Transylvanian basin. The population number has been lost by 85 per cent in the last 200 years and it is still decreasing. Therefore this subspecies is considered to be vulnerable and requires efforts for preservation (Bădărău et al. 2000, 2001).

\section{AIM AND OBJECTIVES}

The aim of our study is to evaluate the genetic diversity and population structure among and within populations of $A$. exscapus ssp. transsilvanicus with the view to provide conservation planning. For this purpose, a SRAP molecular marker system (Li and Quiros, 2001) will be employed for detecting genetic variation in the open reading frames (ORFs) of plant genomes. The procedure requires isolation of genomic DNA, quantification of the purified DNA, polymerase chain reaction and electrophoresis, followed by statistical analysis of the data. For the application of the protocol to a new species like $A$. exscapus ssp. transsilvanicus all these steps have to be optimized and the SRAP primers had to be preliminary tested to allow the large-scale implementation of the procedure to numerous samples.

\section{MATERIALS AND METHODS}

Plant samples were collected from eight natural populations located in the Transylvanian basin. From these, 22 individuals ( 2 or 3 from each population) were randomly chosen for DNA isolation. DNA extraction was performed using the CTAB method (Pop et al., 2008). An initial grinding stage with liquid nitrogen was employed to break down cell wall material and allow access to DNA. We implemented this step of the protocol in two different ways: 1. using the TissueLyser II - Qiagen for 30 seconds,

2. the classic method with mortar grinding.

The quality and quantity of the isolated genomic DNA were determined by spectrophotometry, using the NanoDrop1000 instrument. DNA amplification with SRAP primers was carried out in Corbett-Research PalmCycler under specific conditions. Each $15 \mu \mathrm{l}$ PCR reaction mixture consisted of $1 \times$ Green buffer, $1,5 \mathrm{mM} \mathrm{MgCl}, 200 \mu \mathrm{M}$ of dNTPs, $0,3 \mu \mathrm{M}$ of both forward (Me1) and reverse primer (Em2), $1 \mathrm{U}$ of Taq DNA polymerase (Promega) and approximately $50 \mathrm{ng}$ of template DNA. The PCR was also tested in a $20 \mu \mathrm{l}$ 
Tab. 1

DNA obtained with the TissueLyser

DNA obtained by mortar grinding

\begin{tabular}{|c|c|c|c|c|c|c|c|c|c|}
\hline \multirow{2}{*}{$\begin{array}{c}\text { Sample } \\
\text { no }\end{array}$} & \multirow{2}{*}{ Sample ID } & \multirow{2}{*}{$\begin{array}{c}\text { DNA } \\
\mathrm{ng} / \mu \mathrm{l}\end{array}$} & \multicolumn{3}{|c|}{ Absorbance } & \multirow{2}{*}{$\begin{array}{c}\text { DNA } \\
\mathrm{ng} / \mu \mathrm{l}\end{array}$} & \multicolumn{3}{|c|}{ Absorbance } \\
\hline & & & A260 & A280 & A260/A280 & & A260 & A280 & A260/A280 \\
\hline 1 & B1 & 173.32 & 3.466 & 1.866 & 1.86 & 672.06 & 13.441 & 5.859 & 2.29 \\
\hline 2 & B2 & 175.16 & 3.503 & 1.859 & 1.88 & 590.35 & 11.807 & 5.170 & 2.28 \\
\hline 3 & B3 & 144.92 & 2.898 & 1.571 & 1.85 & 648.03 & 12.966 & 5.610 & 2.31 \\
\hline 4 & G1 & 161.50 & 3.230 & 1.719 & 1.88 & 707.07 & 14.141 & 6.207 & 2.28 \\
\hline 5 & $\mathrm{G} 2$ & 285.19 & 5.704 & 3.086 & 1.85 & 1025.68 & 20.514 & 8.819 & 2.33 \\
\hline 6 & M1 & 218.07 & 4.361 & 2.371 & 1.84 & 2795.74 & 55.915 & 27.949 & 2.00 \\
\hline 7 & M2 & 596.31 & 11.926 & 5.926 & 2.00 & 984.71 & 19.694 & 9.399 & 2.01 \\
\hline 8 & $\mathrm{~S} 1$ & 1165.14 & 23.303 & 11.134 & 2.09 & -11.16 & -0.223 & -0.482 & 0.46 \\
\hline 9 & $\mathrm{~S} 2$ & 1116.83 & 22.337 & 10.997 & 2.03 & 564.63 & 11.293 & 4.839 & 2.33 \\
\hline 10 & S3 & 2159.26 & 43.185 & 20.788 & 2.08 & 556.17 & 11.123 & 4.930 & 2.26 \\
\hline 11 & SG1 & 226.16 & 4.523 & 2.301 & 1.97 & 549.51 & 10.990 & 4.965 & 2.21 \\
\hline 12 & SG2 & 218.77 & 4.375 & 2.395 & 1.83 & 582.22 & 11.644 & 5.152 & 2.26 \\
\hline 13 & SG3 & 537.92 & 10.758 & 5.678 & 1.89 & 233.57 & 4.671 & 5.792 & 0.81 \\
\hline 14 & SI1 & 895.52 & 17.910 & 8.976 & 2.00 & -34.56 & -0.691 & -0.702 & 0.98 \\
\hline 15 & SI2 & 594.69 & 11.894 & 5.986 & 1.99 & 899.44 & 17.989 & 7.836 & 2.30 \\
\hline 16 & SI3 & 330.71 & 6.614 & 3.318 & 1.99 & 765.82 & 15.316 & 6.621 & 2.31 \\
\hline 17 & VF1 & 333.58 & 6.672 & 3.489 & 1.91 & 1231.60 & 24.632 & 11.102 & 2.22 \\
\hline 18 & VF2 & 857.01 & 17.140 & 8.530 & 2.01 & 407.27 & 8.145 & 3.428 & 2.38 \\
\hline 19 & VF3 & 1612.23 & 32.245 & 15.601 & 2.07 & 1613.25 & 32.265 & 14.815 & 2.18 \\
\hline 20 & V1 & 1158.89 & 23.178 & 10.930 & 1.92 & 1264.21 & 25.284 & 11.534 & 2.19 \\
\hline 21 & $\mathrm{~V} 2$ & 218.07 & 4.361 & 2.371 & 1.84 & 1440.86 & 28.817 & 12.965 & 2.22 \\
\hline \multirow[t]{3}{*}{22} & V3 & 144.92 & 2.898 & 1.571 & 1.85 & 2843.47 & 56.869 & 26.757 & 2.13 \\
\hline & \multicolumn{2}{|c|}{ Standard deviation } & & & 0.19 & & & & 6.05 \\
\hline & Average & 605.644 & 12.112 & 6.021 & 1.947 & 924.100 & 18.481 & 8.571 & 2.033 \\
\hline
\end{tabular}

volume, adding $1 \mu \mathrm{l}$ polyvinylpyrrolidone (PVP, m.w. 2500030000, Merck) as an antioxidant.

\section{RESULTS AND DISCUSSION}

After DNA isolation we measured the quantity of the extracted DNA $(\mathrm{ng} / \mu \mathrm{l})$ and the quality of it. The ratio of absorbance at $260 \mathrm{~nm}$ and $280 \mathrm{~nm}$ is used to assess the purity of DNA. If the ratio $260 / 280$ of the two readings has values between 1.7 and 2.0, DNA is considered pure enough for further analysis. The spectrometry measurements are represented in Table 1. Although the average DNA quantity obtained by classical grinding is higher, the TissueLyser provided sufficient amount of DNA with satisfactory purity. As it can be noticed, standard deviation for the first method is significantly smaller comparatively with the second method. This is a good indicator of the fact that even if the average values of the ratio A260/A280 are almost equal indeed there are qualitative differences between the two methods applied on the samples. Moreover, the TissueLyser method is faster and uses less amount of liquid nitrogen, which justifies further use in larger number of samples.

\section{CONCLUSION}

Regarding the optimal volume for the polymerase chain reaction, there were no significant differences between the two alternatives (15 or $20 \mu$ l volume). In conclusion, for further analysis we will employ the PCR protocol with a 15 $\mu \mathrm{l}$ reaction volume and TissueLyser method to extract DNA for the large-scale implementation of the procedure.

Aknowledgement. This paper was published under the frame of European Social Fund, Human Resources Development Operational Programme 2007-2013, project no. POSDRU/159/1.5/S/132765

\section{REFERENCES}

1. Bădărău Al. S., Dezsi St., Comes O., (2000), Cercetări biogeografice asupra speciilor stepice -silvostepice de Astragalus $L$. din depresiunea Transilvaniei, Studia universitatis Babes-Bolyai, Geographia, XLV, 2.

2. Bădărău Al. S., Dezsi St., Man T., (2001), Cercetări biogeografice asupra speciilor stepice -silvostepice de Astragalus L. din depresiunea Transilvaniei (II), Studia universitatis Babes-Bolyai, Geographia, XLVI, 1.

3. Li G. and Quiros C. F., (2001). Sequence-related amplified polymorphism (SRAP), a new marker system based on a simple PCR reaction: its application to mapping and gene tagging in Brassica. Theor. Appl. Genet., 103:455-461.

4. Pop Rodica, (2008) Studiul variabilității somaclonale la vița de vie cu ajutorul markerilor molecular Editura Bioflux, Cluj-Napoca 